\title{
Selection of Phalaenopsis amabilis L. Blume Orchid Resistance to Hygromycin
}

\author{
Ixora Sartika Mercuriani ${ }^{1,2}$, Aziz Purwantoro ${ }^{3}$, Sukarti Moeljopawiro 4 , \\ Seonghoe Jang ${ }^{5}$, and Endang Semiarti ${ }^{4^{*}}$
}

${ }^{1}$ Doctoral Program of Biotechnology, Graduate School of Universitas Gadjah Mada, Yogyakarta, Indonesia

${ }^{2}$ Department of Biology Education, Faculty of Mathematics and Science, Universitas Negeri Yogyakarta, Indonesia

${ }^{3}$ Faculty of Agriculture, Universitas Gadjah Mada, Yogyakarta, Indonesia

${ }^{4}$ Faculty of Biology, Universitas Gadjah Mada, Yogyakarta, Indonesia

${ }^{5}$ Agricultural Biotechnology Research Center, Academia Sinica Biotechnology Center Southern Taiwan, Tainan County, Taiwan, Republic of China

\begin{abstract}
Examination of Phalaenopsis amabilis orchid resistance to hygromycin antibiotic is an important step to do prior to Agrobacterium-mediated genetic transformation in this orchids using Hygromycin phosphotransferase $(H P T)$ gene as a selection marker in the T-DNA that harboring a desired gene to be transfered. We exposed the plant on hygromycin containing medium. The experiment was conducted using 6 weeks old P. amabilis protocorms. These protocorms were subcultured onto NP medium supplemented with various concentration of Hygromycin $(0,5,10,20,1 \mathrm{nd} 40 \mathrm{mg} / \mathrm{l})$. The number of survival protocorms were examined every week for 4 weeks after subcultured (WAS). The resistancy of hygromycin was calculated as ratio of death protocorms per total protocorms). The result showed that $10 \mathrm{mg} / 1$ hygromycin with 1 weeks of application caused death close to LD 50. This data indicate that $P$. amabilis resistance to hygromycin treatment on the appropriate concentration $10 \mathrm{mg} / \mathrm{l}$, and this concentration can be used for other purposes in orchid system.
\end{abstract}

Key words: hygromycin, resistance, LD50, P. amabilis, protocorm

\section{Introduction}

Antibiotics are known as a drug for its ability to inhibit bacterial infection. Antibiotics can inhibit physiological and biochemical processes resulting in growth inhibition of cell and death. There are five major targets of antibiotics on bacterial cells, i.e.: cell wall, cell membrane, the synthesis of protein, RNA and DNA synthesis, and metabolism of folic acid (Wright, 2010). Some types of antibiotics can also inhibit protein synthesis in eukaryotes. Antibiotics genetisin

\section{*Corresponding Author:}

Endang Semiarti

Faculty of Biology, Universitas Gadjah Mada, Jl. Teknika Selatan, Sekip Utara, Yogyakarta, Indonesia, 55281, Email: endsemi@ugm.ac.id
(G418) and hygromycin (aminoglycoside antibiotic whose structure is similar to the G418), are highly effective in inhibiting protein synthesis in eukaryotic cells because it binds to the 80s ribosomal complexes (Mingeot-Leclercq et al., 1999). Both of these antibiotics are now commonly used in the study of molecular biology, mainly to select eukaryotic cells that have been inserted with targeted genes.

The ability of antibiotics to inhibit cell growth is also affected by the mechanism of cell resistance to antibiotics. Wright (2010) reported that there were four common mechanisms of resistance; i.e. the targeted modification, efflux, immunity, and destruction by enzymes. Some modifications occur through mutation of the target itself, for 
example by producing an enzyme that induces the methylation of ribosomes so that the presence of antibiotics was not able to inhibit protein synthesis. Efflux occurs through the activity of trans-membrane proteins (protein pump) to pump the antibiotic out of the cell. On the mechanism of immunity, antibiotics into the cell or the target of the antibiotic is bound by a protein so that antibiotics cannot bind to the target. Meanwhile, a very specific mechanism is destruction by enzymes. The enzyme is able to recognize the antibiotic and modify / alter the functional side so it can not bind to the target.

$P$. amabilis is one of wild orchids that is widely used as a parental to produce moth orchid hybrids. Improving the quality of orchids, i.e. increased variation style, color, size, shape, and number of flowers; increased number of shoots, as well as resistance to pests and diseases, is carried out to meet the market needs. Genetic transformation is one of the alternative technologies that can be used to improve quality.

Improved methods of transformation have been reported to improve the efficiency of transformation for each cultivar. The use of appropriate selection marker is an important step in the improvement of the method. Selection marker is required to select the transformants and to exclude nontransformants. About 50 selection markers have been used for many higher plants (Miki and McHugh, 2004), including the genes encoding resistance to antibiotics and herbicides (such as neomycin phosphotransferase (NPTII), hygromycin phosphotransferase (HPT), and bialaphos resistance (Bar). Genes encoding resistance to kanamycin (NPTII) was effectively used as a selection marker for dicot crops, such as tobacco, tomato, and Arabidopsis (An et al., 1986; Mentewab and Stewart, 2005; Parveez et al., 2007). However, for monocot crops such as rice and maize, the use of HPT or Bar proved the most effective (Hiei et al., 1994; Ishida et al., 1996).

In addition to the determination of an appropriate selection marker for each cultivar, the determination of the exact concentration of the selection agent is also needed. In several studies, hygromycin selection proved to be the most effective agent because it inhibit plant cell growth at low concentrations (Duan and Din, 2007; Parveez et al., 2007; Sreeramanan et al., 2006; Torregrosa et al., 2000). Selection using hygromycin require much lower concentrations (between 1-50 mg/1) compared with kanamycin (50-500 mg/l). At a concentration of $20 \mathrm{mg} / \mathrm{l}$, hygromycin able to inhibit the growth of single banana shoots in vitro (Sreeramanan et al., 2006). Color bud then turn brown or black indicating cell death. In vines, hygromycin with lower concentration (1-4 mg/l) was able to cause necrosis (Torregrosa et al., 2000). Genetic transformation on various types of orchids are also used HPT as a marker selection. Hygromycin concentrations that was used for selection of orchids candidate transformants on different cultivars or types of explants were varies between 3-50 mg/1 (Belarmino and Mii, 2000; Liau et al., 2003; Mishiba et al., 2005; Shrestha et al., 2007; Zhang et al., 2010). The purpose of this study was to determine the optimal hygromycin concentration to inhibit or cause cell death of $P$. amabilis orchid protocorm.

\section{Materials and Methods \\ Hygromycin selection}

This experiment was conducted at Laboratory of Biotechnology, Faculty of Biology, Universitas Gadjah Mada, Yogyakarta for 3 months, from September to November 2012. Plant materials that were used in this study were protocorms (developping orchid embryos) of Phalaenopsis amabilis (L.) Blume aged 6 weeks after planting (WAP). Protocorms were generated by sowing orchid seeds from mature fruit (4 month after fertilization) on modified New Phalaenopsis (NP) medium by the addition of $150 \mathrm{ml} / 1$ coconut water and $100 \mathrm{mg} / 1$ tomato extract (Islam et al., 1998; Semiarti et al., 2010). The P. amabilis fruit was obtained 
from Laboratory of Biotechnology, Faculty of Biology, UGM, Yogyakarta.

Six weeks old protocorms were subcultured on selection medium (NP containing $15 \%$ coconut water) with various concentrations of hygromycin, namely: $0,5,10,20$, and 40 $\mathrm{mg} / \mathrm{l}$. Each treatment was repeated four times. The inhibition of protocorms growth was observed every week until the level of death protocorm close to $100 \%$. Observations were made through the image to facilitate quantitative data collection.

\section{PCR analysis}

Total genomic DNA was extracted from the leaves of transformed and non-transformed plants by the CTAB method. A pair of specific primer for HPT gene as follows: HPT F 5'TGCGCCCAAGCTGCATCAT-3'and HPT R 5'-TGAACTCACCGCGACGTCTGT-3' were used for PCR analysis. The expected product size was 810 base pairs (bp). Reaction conditions were as follows: predenaturation at $94^{\circ} \mathrm{C}$ for $5 \mathrm{~min}$ followed by 35 amplification cycles (denaturation: $94^{\circ} \mathrm{C}$ for $60 \mathrm{sec}$, annealing: $69^{\circ} \mathrm{C}$ for 30 sec, elongation: $72^{\circ} \mathrm{C}$ for $90 \mathrm{sec}$ ) and final extension step at $72^{\circ} \mathrm{C}$ for $5 \mathrm{~min}$. As internal control, a pair of specific primer for intergenic region of chloroplast (CP) DNA (trnLF C 5'-CGAAATCGGTAGACGCTACG-3' and trnLF F 5'- ATTTGAACTGGTGACACGAG -3') were used (Gardiner et al., 2007). The plasmid DNA pGAS102 was amplified using the same primer and condition as positif control. The expected product size was 1200 $\mathrm{bp}$. The same reaction conditions were used, except for annealing temperature $\left(55^{\circ} \mathrm{C}\right)$. The PCR products were visualized by running the completed reaction on a $1 \%$ agarose gel containing Good View ${ }^{\mathrm{TM}}$ Nucleic Acid Stain (Beijing SBS Genetech Co., Ltd.).

\section{Results and Discussion}

Hygromycin inhibited the growth and then causing the death of $P$. amabilis protocorms in all concentrations that was used in this experiment (Table 1 and Figure 1 ) even at the lowest concentration $(5 \mathrm{mg} / \mathrm{l})$.

The death level of protocorms that was cultured on NP medium with $5 \mathrm{mg} / 1$ was quite low in 1 week after subcultured (WAS) $(14.8 \%)$, but then increased in the following weeks and reached $58.4 \%$ in 4 WAS. Medium NP with $10 \mathrm{mg} / 1$ hygromycin caused death $57.6 \%$ in $1 \mathrm{WAS}$, therefore this concentration was the closest to LD50 (the concentration that result death as many as $50 \%)$. The death level in this medium then increased in the following weeks and reach $96.2 \%$ in 4 WAS. Medium NP with 20 and 40 $\mathrm{mg} / 1$ hygromycin caused severe death (90.5 and $99.3 \%$ ) in 1 WAS. Protocorm that was cultured on hygromycin-containing medium at concentrations of 10,20 , and $40 \mathrm{mg} / 1 \mathrm{had}$ the highest mortality rate in 1 WAS (Figure $2)$, whereas the mortality rate in the following weeks $(2,3$, and 4$)$ declined. The decline in 2,3 , and 4 WAS presumably due to the decreased concentration of hygromycin in the medium due to plant absorbtion.

The hygromycin concentration required to select transformant that carry HPT gene was a concentration that kill non-transformant cells but did not interfere the growth of transformant cells. The results of this study indicate the optimum concentration for this selection was $10 \mathrm{mg} / 1$ for 4 week of application. Inhibition of growth or death process should not running too fast. It is expected to provide an opportunity for transformant cells to build of plant resistance. Wright (2010) explained that there were four common mechanisms of resistance; i.e. the targeted modification, efflux, immunity, and destruction by enzymes. Too high concentration of hygromycin provide severe toxic effects for transformant cells, did not able to develop the resistance system. This condition inhibits plant regeneration and induce plant death .

A preliminary study to support genetic engineering technology harboring hygromycin as selection agent has been carried out. Molecular analysis has been carried out by amplify HPT gene using specific HPT primers (HygF and HygR). 
Table 1. Percentage of Death Protocorm Phalaenopsis amabilis in Hygromycin

\begin{tabular}{|c|c|c|c|c|c|c|c|c|c|c|c|c|}
\hline \multirow{3}{*}{$\mathrm{T}$} & \multirow{3}{*}{$\mathrm{R}$} & \multirow{3}{*}{$\mathrm{n}$} & \multicolumn{10}{|c|}{$\begin{array}{l}\text { Percentage of Death Protocorm } \\
\text { in } 0,1,2,3 \text {, and } 4 \text { WAS }(\%)\end{array}$} \\
\hline & & & \multicolumn{2}{|r|}{0} & \multicolumn{2}{|r|}{1} & \multicolumn{2}{|c|}{2} & \multicolumn{2}{|c|}{3} & \multicolumn{2}{|c|}{4} \\
\hline & & & $\%$ & $\mathrm{r} \pm \mathrm{sd}$ & $\%$ & $\mathrm{r} \pm \mathrm{sd}$ & $\%$ & $r \pm s d$ & $\%$ & $r \pm s d$ & $\%$ & $r \pm s d$ \\
\hline \multirow[t]{3}{*}{0} & 1 & 444 & 0.0 & & 0.0 & & 0.0 & & 0.0 & & 0.0 & \\
\hline & 2 & 237 & 0.0 & $0.0 \pm 0.0$ & 0.0 & $0.0 \pm 0.0$ & 0.0 & $0.0 \pm 0.0$ & 0.0 & $0.0 \pm 0.0$ & 0.0 & $0.0 \pm 0.0$ \\
\hline & 3 & 411 & 0.0 & & 0.0 & & 0.0 & & 0.0 & & 0.0 & \\
\hline \multirow[t]{3}{*}{5} & 1 & 343 & 0.0 & & 10.8 & & 33.2 & & 41.7 & & 61.5 & \\
\hline & 2 & 216 & 0.0 & $0.0 \pm 0.0$ & 19.0 & $14.8 \pm 4.1$ & 27.3 & $27.8 \pm 5.2$ & 41.7 & $39.0 \pm 4.7$ & 55.1 & $58.4 \pm 3.5$ \\
\hline & 3 & 351 & 0.0 & & 14.5 & & 22.8 & & 33.6 & & 55.8 & \\
\hline \multirow[t]{3}{*}{10} & 1 & 394 & 0.0 & & 57.4 & & 72.6 & & 84.8 & & 96.7 & \\
\hline & 2 & 310 & 0.0 & $0.0 \pm 0.0$ & 53.9 & $57.6 \pm 3.9$ & 79.0 & $74.8 \pm 3.7$ & 88.1 & $85.3 \pm 2.5$ & 95.2 & $96.2 \pm 0.9$ \\
\hline & 3 & 559 & 0.0 & & 61.7 & & 72.6 & & 83.2 & & 96.6 & \\
\hline \multirow[t]{3}{*}{20} & 1 & 232 & 0.0 & & 90.1 & & 94.4 & & 97.8 & & 100.0 & \\
\hline & 2 & 201 & 0.0 & $0.0 \pm 0.0$ & 90.0 & $90.5 \pm 0.7$ & 95.0 & $94.4 \pm 0.6$ & 97.5 & $97.6 \pm 0.2$ & 99.5 & $99.7 \pm 0.3$ \\
\hline & 3 & 456 & 0.0 & & 90.2 & & 93.9 & & 97.4 & & 99.6 & \\
\hline \multirow[t]{3}{*}{40} & 1 & 453 & 0.0 & & 99.3 & & 100.0 & & 100.0 & & 100.0 & \\
\hline & 2 & 357 & 0.0 & $0.0 \pm 0.0$ & 99.4 & $99.3 \pm 0.1$ & 100.0 & $99.8 \pm 0.3$ & 100.0 & $99.9 \pm 0.1$ & 100.0 & $100 \pm 0.0$ \\
\hline & 3 & 392 & 0.0 & & 99.2 & & 99.5 & & 99.8 & & 100.0 & \\
\hline
\end{tabular}

Note:

$\mathrm{T}:$ Hygromycin Concentration $(\mathrm{mg} / \mathrm{l})$

$\mathrm{R}$ : Replication

$r$ : Percentage Average of Death Protocorm

$\mathrm{n}$ : Number of Protocorm

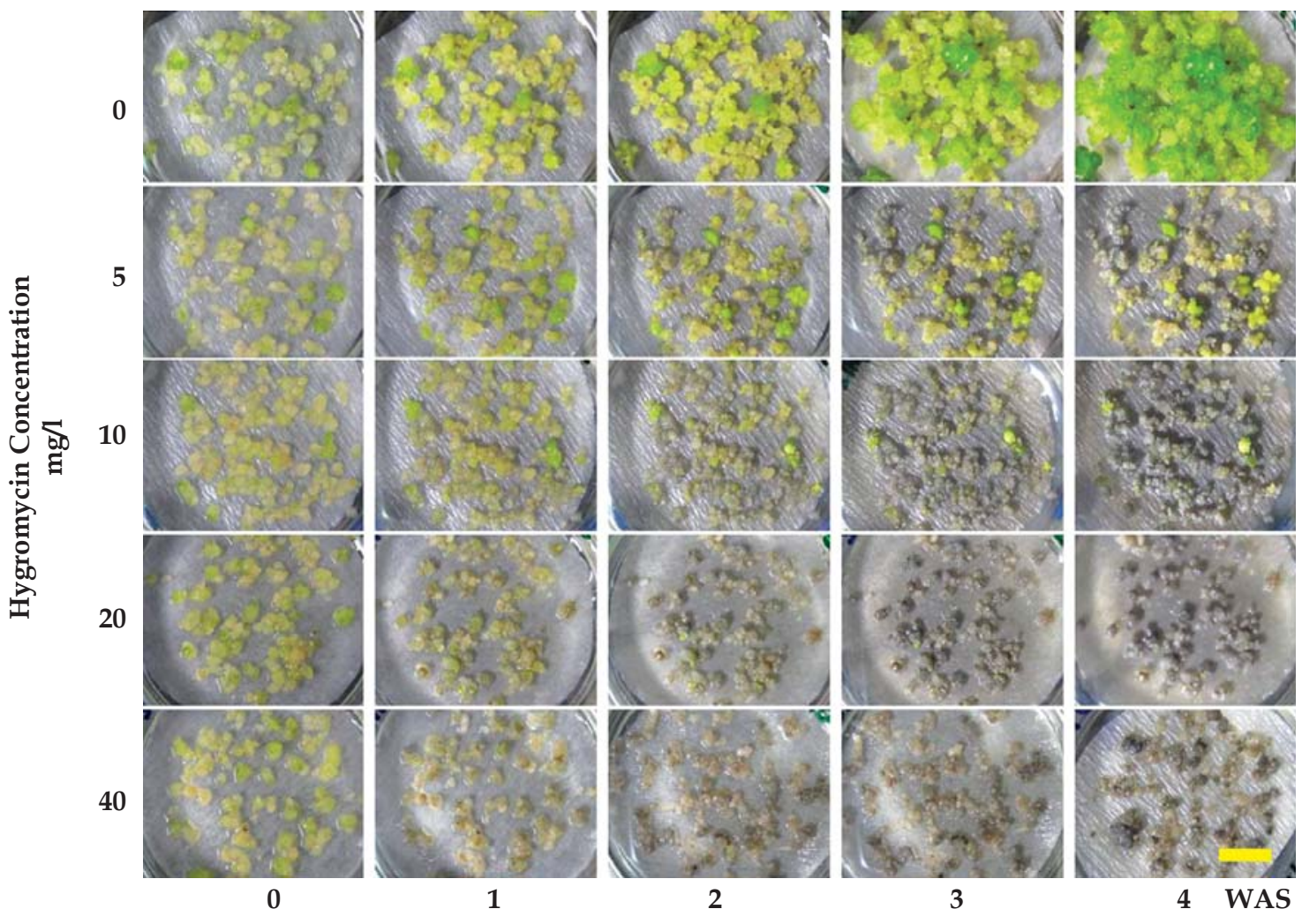

Figure 1. The death level of Protocorm on NP medium with various hygromycin concentration $(0,5,10,20$, and 40 $\mathrm{mg} / \mathrm{l}$ ) in $0,1,2,3$, and 4 WAS. Bar: $1 \mathrm{~cm}$. 


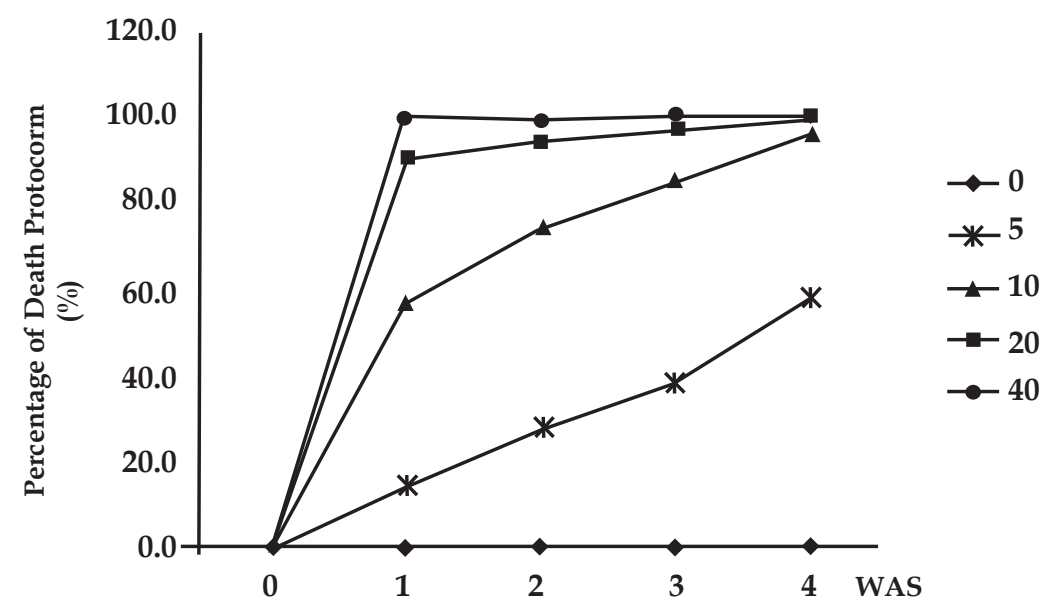

Figure 2. Protocorm death rate on various concentration of hygromycin $(0,5,10$, 20 , and $40 \mathrm{mg} / \mathrm{l}$ ) in $0,1,2,3$, and 4 WAS.

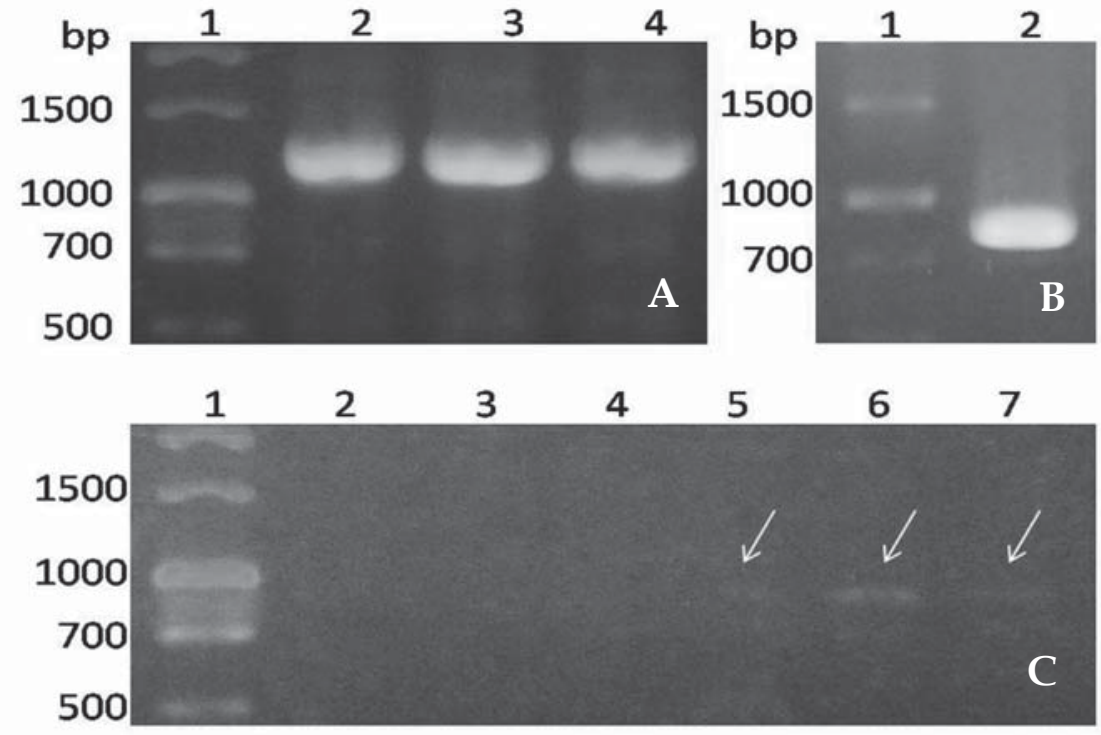

Figure 3. Molecular analysis of wild orchid P. amabilis genome. A, trnLF amplification: 1 kb DNA ladder, Bioron (line1); wild orchid P. amabilis genome (line 2, 3, and 4). B, HPT amplification: $1 \mathrm{~kb}$ DNA ladder, Bioron (line1) and HPT containing plasmid (line 2). C, HPT amplification: 1 kb DNA ladder, Bioron (line1); wild orchid P. amabilis genome (line 2, 3, and 4); and HPT containing transformant genome (line 5, 6, and 7)

The results indicated that there was no HPT gene in wild type of $P$. amabilis genome. There was no 810 bp DNA fragment as it should be owned by the transgenic plants or DNA plasmid carrying the HPT gene (Figure 4). In this analysis, amplification of trnL-F intergenic region of chloroplast genom was also conducted as an internal control. The $1200 \mathrm{bp}$ fragments that were successfully amplified indicate that DNA used in this amplification (both for HPT and trnLF amplification) is in good condition.

Astheconclusion, effective concentration of Hygromycin antibiotics that suitable as selectable marker for Phalaenopsis amabilis orchid is $10 \mathrm{mg} / \mathrm{l}$. This concentration can be applied for Agrobacterium-mediated genetic transformation in this orchids. 


\section{Acknowledgments}

This work is supported by a Research Grant ofSTRANAS 2012 from DGHE, Ministry of Education and Culture RI contract No. 001/ SP2H/PL/Dit.litabmas/III/ 2012

\section{References}

An, G., Watson, BD, and Chiang, CC, 1986. Transformation of Tobacco, Tomato, Potato, and Arabidopsis thaliana using a Binary Ti Vector System. Plant Physiol., 81, 301-305.

Belarmino, M.M. and Mii, M. 2000. Agrobacterium-mediated genetic transformation of a Phalaenopsis orchid. Plant Cell Rep., 19, 435-442.

Duan, H. and Din, X. 2007. Effects of Hygromycin on Growth and Development of Arabidopsis Seedling Roots. Pak. J. Bot., 39, 6, 2167-2173.

Gardiner, L.M., 2007. Vanda tricolor Lindl. Conservation in Java: Genetic ang geographic structure and history. Proceeding of The $3^{\text {rd }}$ International Orchid Conservation Congress, San Jose, Costa Rica March 19-24, 272-280.

Hiei, Y., Ohta, S., Komari, T., Kumashiro, T., 1994. Efficient transformation of rice (Oryza sativa L.) mediated by Agrobacterium and sequence analysis of the boundaries of the T-DNA. Plant J., 6, 271-282.

Ishida, Y., Saito, H., Ohta, S., Hiei, Y., Komari, T., Kumashiro, T., 1996. High efficiency transformation of maize (Zea mays L.) mediated by Agrobacterium tumefaciens. Nat.Biotechnol., 14, 745-750.

Islam, M.O., Ichihasi, S., and Matsui, S., 1998. Control of growth and development of protocorm-like body derived from callus by carbon sources in Phalaenopsis. Plant Biotech., 15, 183-187.

Liau C.H., You, S.J., Prssad, V., Hiou, H.H., Lu, J.C., Yang, N.S., Chan, M.T., 2003. Agrobacterium tumefaciens-mediated transformation of an Oncidium orchid. Plant Cell Rep., 21, 993-998.

Mentewab, A. and Stewart Jr, CN., 2005. Overexpression of an Arabidopsis thaliana
ABC transporter confers kanamycin resistance to transgenic plants. Nature Biotech., 23, 9, 1177-1180.

Miki, B and McHugh, S., 2004. Selectable marker genes in transgenic plants: applications, alternatives and biosafety. J. Biotech., 107, 193-232.

Mingeot-Leclercq, M., Glupczynski, Y., and Tulkens, PM., 1999. Aminoglycosides: Activity and Resistance. Antimicrob. Agents Chemother., 43, 4, 727-737.

Mishiba K.I., Chin, D.P., Mii, M., 2005. Agrobacterium-mediated transformation of Phalaenopsis by targeting protocorm at an early stage after germination. Plant Cell Rep., 24, 297-303.

Parveez, GKA., Majid, NA., Zainal, A., Rasid, OA. 2007. Determination of minimal inhibitory concentration of selection agents for selecting transformed immature embryos of oil palm. As.Pac J. Mol. Biol. Biotechnol., 15, 3, 133-146.

Semiarti, E., Indrianto, A., Purwantoro, A., Martiwi, I.N.A., Feroniasanti, Y.M.L, Nadifah, F., Mercuriani, I.S, Dwiyani, R., Iwakawa, H., Yoshioka, Y., Machida, Y., and Machida, C., 2010. High-frequency genetic transformation of Phalaenopsis amabilis orchid using tomato extractenriched medium for the pre-culture of protocorms. J. Hort. Sci. Biotech., 85, 3, 205-210.

Shrestha, B.R, Chin, D.P, Tokuhara, K., and Mii, M. 2007. Efficient production of transgenic plantls of Vanda through sonication-assisted Agrobacterium-mediated transformation of protocorm-like bodies. Plant Biotechnol., 24, 429-434.

Sreeramanan, S., Maziah, M., Abdullah, MP., Rosli, NM., Xavier, R., 2006. Potential Selectable Marker for Genetic Transformation in Banana. Biotechnology, 5, 2, 189-197.

Torregrosa, L., Lopez, G., Bouquet, A., 2000. Antibiotic Sensitivity of Grapevine: A Comparison Between The Effect of Hygromycin and Kanamycin on Shoot Development of Trangenic 110 
Richter Rootstock (Vitis berlandieri x Vitis Rupestris). S.Afr.J.Enol.Vitic., 21, 1, 32-39. Wright, G.D. 2010. Antibiotic Resistance: where does it come from and what can we do about it? BMC Biology, 8, 123, 1-6. http://www.biomedcentral.com/17417007/8/123.

Zhang, L., Chin, D.P., Fukami, M., Ichikawa, H., Nakamura, I., Mii, M., 2010. Agrobacterium-mediated transformation of Cattleya with an Odontoglossum ringspot virus replicase gene sequence. Plant Biotechnol., 27, 421-426. 